\title{
Genes for extracellular matrix-degrading metalloproteinases and their inhibitor, TIMP, are expressed during early mammalian development
}

\author{
Carol A. Brenner, ${ }^{1}$ Richard R. Adler, ${ }^{2}$ Daniel A. Rappolee, Roger A. Pedersen, and Zena Werb ${ }^{3}$ \\ Laboratory of Radiobiology and Environmental Health, and Department of Anatomy, University of California, San Francisco, \\ California 94143-0750 USA
}

\begin{abstract}
Extracellular matrix (ECM) remodeling accompanies cell migration, cell-cell interactions, embryo expansion, uterine implantation, and tissue invasion during mammalian embryogenesis. We have found that mouse embryos secrete functional ECM-degrading metalloproteinases, including collagenase and stromelysin, that are inhibitable by the tissue inhibitor of metalloproteinases (TIMP) and that are regulated during peri-implantation development and endoderm differentiation. mRNA transcripts for collagenase, stromelysin, and TIMP were detected as maternal transcripts in the unfertilized egg, were present at the zygote and cleavage stages, and increased at the blastocyst stage and with endoderm differentiation. These data suggest that metalloproteinases function in cell-ECM interactions during growth, development, and implantation of mammalian embryos.
\end{abstract}

[Key Words: Collagenase; stromelysin; polymerase chain reaction; tissue inhibitor of metalloproteinases; maternal mRNA; endoderm differentiation]

January 31, 1989; revised version accepted March 15, 1989.

The extracellular matrix (ECM) forms a substrate for cell attachment and migration and directs cell form and function through cell-ECM interactions. ECM macromolecules first appear in the mammalian embryo in the initial cleavage stages and then accumulate in increasing amount and complexity during the blastocyst stage, implantation in the uterine wall, and differentiation into embryonic and extraembryonic tissues (Critchley et al. 1979; Wartiovaara et al. 1979; Adamson 1982; Cooper and MacQueen 1983). It is likely that remodeling of ECM accompanies the changes in embryonic and uterine tissues that occur during development. In uterine involution, tumor invasion, and rheumatoid arthritis, remodeling of the ECM requires extracellular proteolytic enzymes (Werb 1989). A multigene family of metal-dependent proteinases, the metalloproteinases, have been implicated as the key, rate-limiting enzymes in ECM degradation (Werb 1989). The best-characterized metalloproteinases are collagenase, an enzyme that degrades collagens of types I, II, III, VIII, and X (Murphy and Reynolds 1985; Werb 1989); stromelysin, a broadspectrum enzyme that degrades fibronectin, proteoglycans, type IV collagen, and laminin (Chin et al. 1985; Herron et al. 1986a); and a gelatinase of $68 \mathrm{kD}$ that degrades collagens of types IV, V, and VII /Collier et al.

Present addresses: ${ }^{1}$ Genelabs, Inc., 505 Penabscot Drive, Redwood City, California 94063 USA; ${ }^{2}$ Department of Biology, Western Carolina University, Cullowhee, North Carolina 28723 USA.

${ }^{3}$ Corresponding author.
1988|. The activity of these proteinases is regulated by the tissue inhibitor of metalloproteinases (TIMP) (Murphy et al. 1985; Herron et al. 1986a,b; Gavrilovic et al. 1987).

Little is known about the proteolytic mechanisms involved in the remodeling of ECM during early development. The initial attachment and adhesion of the trophoblast to the uterine epithelium is dependent upon components of the uterine stromal ECM, such as collagen (Sherman et al. 1980; Armant et al. 1986). Plasminogen activators $(\mathrm{PA})$, which are serine proteinases, have been found at the time of mouse implantation and in oocytes and are expressed by both trophoblast cells and parietal endoderm (Strickland et al. 1976, 1988; Kubo et al. 1982; Huarte et al. 1987). However, because of its limited substrate specificity, PA alone is not sufficient for tissue invasion and degradation of ECM components such as collagen (Werb et al. 1977; Mignatti et al. 1986).

Our understanding of molecular events that govern differentiation during early mammalian embryogenesis is largely incomplete owing to the difficulty in obtaining sufficient amounts of embryonic material. Several technical advances have allowed us to overcome these limitations. In this study, we determined proteinase activity in small volumes of embryo secretions by sensitive zymographic procedures, and we used the inhibitor TIMP to show that metalloproteinases are present in peri-implantation development. We analyzed mRNA tran- 
scripts for stromelysin, collagenase, and TIMP in unfertilized eggs and preimplantation mouse embryos by a novel RNA phenotyping procedure based on the polymerase chain reaction (PCR). This procedure is sensitive to $\leqq 10$ RNA transcripts and can detect mRNA in a single cell (Rappolee et al. 1988a,b; 1989).

\section{Results \\ Mouse embryos secrete functional proteinases}

We first used zymography on SDS-gelatin or SDS-casein gels to determine whether catalytically active ECM-degrading proteinases are secreted during mouse embryogenesis. In general, gelatin-degrading proteinases have substrate preferences more like collagenases, and casein-degrading proteinases are more like stromelysin (Werb 1989). Proteinases were detected in serum-free medium conditioned for $24 \mathrm{hr}$ by unfertilized eggs (mature oocytes), preimplantation embryos, and blastocyst outgrowths, and in medium conditioned for $4 \mathrm{hr}$ by egg cylinder-stage embryos (7.5 days of gestation [d.g.]) (Fig. 1). Unfertilized eggs secreted two major gelatinases of 68 and $92 \mathrm{kD}$; secretion of these proteinases continued after fertilization to the two-cell stage, decreased during the two- to four-cell stage, and remained low during the eight-cell to morula stages (Fig. 1). The two-cell stage, when secretion of the gelatinases decreased, corresponds to the time of transition from the translation of maternal to zygotic transcripts (Schultz et al. 1979a,b; Schultz 1986). Gelatinase secretion increased during the blastocyst stage, with increased activity of the 68- and $92-\mathrm{kD}$ bands and the appearance of additional bands at 75 and $85 \mathrm{kD}$. In some experiments with higher embryo concentrations, a weak gelatinase at $\sim 50 \mathrm{kD}$ comigrating with rabbit procollagenase was detected (Fig. $1 \mathrm{C}$. There was a large increase in the activity of proteinases, particularly the $92-\mathrm{kD}$ gelatinase, during blastocyst outgrowth, a process corresponding to acquisition of invasiveness during implantation and early postimplantation development in vivo (Glass et al. 1983). Cultured egg cylinder-stage embryos secreted even more of these proteinases. Zonae pellucidae isolated from early blastocysts (4.5 d.g.) showed no gelatinase activity, thus ruling out the possibility that the embryonic proteinases had been absorbed by the zonae pellucidae in the uterus and then released in culture.

Embryos were also assayed for the secretion of caseindegrading proteinases (Fig. 1A,C). Although the eggs and cleavage-stage embryos occasionally showed very lowlevel secretion of a $\sim 40-\mathrm{kD}$ caseinase comigrating with active rabbit prostromelysin, little significant caseinase activity was observed until the blastocyst stage, when embryos began to secrete caseinases migrating at 40,51 , 130 , and $180 \mathrm{kD}$. The bands at 40 and $51 \mathrm{kD}$, which comigrate with rabbit stromelysin and prostromelysin, were also seen in blastocyst outgrowths. Although there were some quantitative differences in relative band strength from one experiment to another, the developmental regulation of the proteinases was qualitatively seen in more than five experiments. These data demon- strate that during peri-implantation development there is developmentally regulated expression of several proteinases that degrade gelatin or casein.

\section{Proteinases are secreted by the first differentiated tissues of the embryo in distinct patterns}

Preimplantation development culminates in the differentiation of the trophectoderm, which surrounds the blastocyst cavity, and the inner cell mass (ICM) within that cavity. With further development the trophectoderm is involved in the implantation of the embryo in the maternal uterine wall and eventually contributes to the fetal portion of the placenta (for review, see Pedersen 1988). The ICM contributes to the extraembryonic membranes and the fetus. To determine the relative secretion of proteinases by trophectoderm and ICM cells, the proteinase secretion of intact late blastocysts was compared with that of immunosurgically isolated ICMs (Fig. 1A,C). The blastocysts at this stage secreted gelatinases of $68,75,92,120$, and $130 \mathrm{kD}$, and the ICMs showed a similar pattern of secretion, with additional bands at 70 and $85 \mathrm{kD}$, although there was some variability in relative band intensity between experiments. Because of the tight junctions between the trophectodermal cells, the secreted proteinases of blastocysts would be expected to be enriched in secretions from the external surface of the trophectoderm. ICMs isolated from late blastocysts regenerated very little trophectoderm during the $48-\mathrm{hr}$ culture, and thus the proteinases in the medium should derive mostly from ICM cells. This supposition was confirmed by $x$-irradiating the ICMs before culture, so that only trophectoderm survived (Goldstein et al. 1975). Very little proteinase secretion was observed under these conditions, suggesting that little trophectoderm contaminated the ICMs. Proteinases secreted by $\mathrm{x}$-irradiated blastocyst outgrowths also were studied. Blastocyst outgrowths have primarily trophoblast cells. Outgrowths and ICMs had distinctly different patterns of secreted proteinases. After x-irradiation only trophoblast cells survive, and outgrowths derived from $\mathrm{x}$-irradiated blastocysts showed the major 92-kD gelatinase seen in unirradiated blastocyst outgrowths, as well as much more of the $68-\mathrm{kD}$ gelatinase. Intact blastocysts secreted four minor casein-degrading proteinases at $43,85,90$, and $97 \mathrm{kD}$, whereas ICMs showed less activity at 43 or $85 \mathrm{kD}$ but increased activity at 90 and $97 \mathrm{kD}$ (Fig. 1B,C). These data suggest that there may be both ICM- and trophectoderm-specific proteinases.

\section{The functional proteinases secreted by embryos are all metalloproteinases}

To determine the class of the secreted embryonic proteinases, these proteinases were separated on the substrate gels and then incubated with TIMP. Virtually all of the proteolytic activity secreted by embryos that was detected by zymography on SDS-gelatin gels was inhibited by TIMP, providing the first evidence that the major 
A

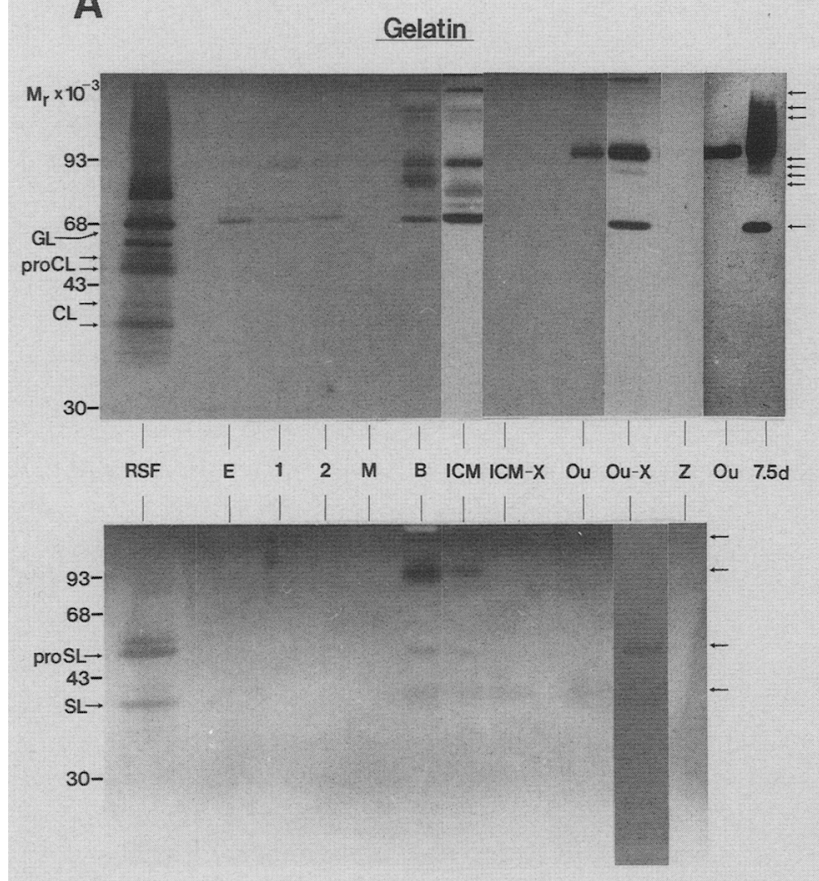

Casein
B

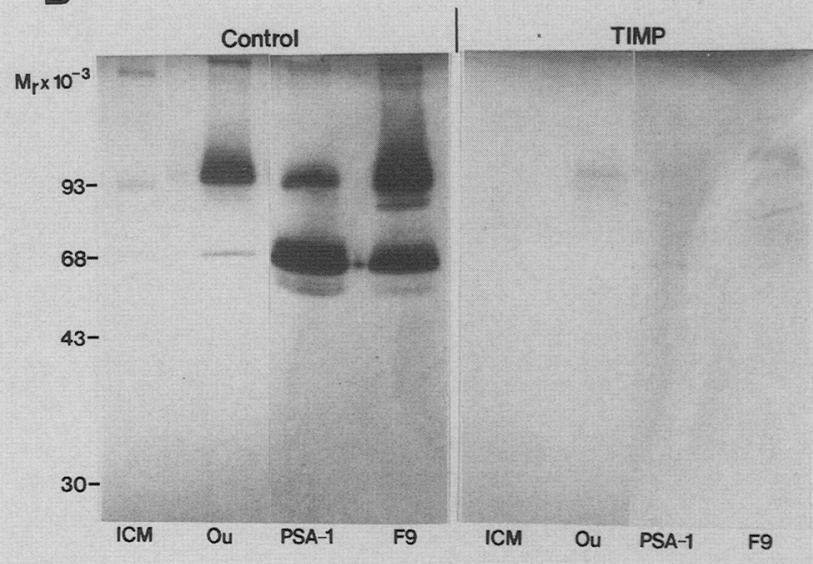

C
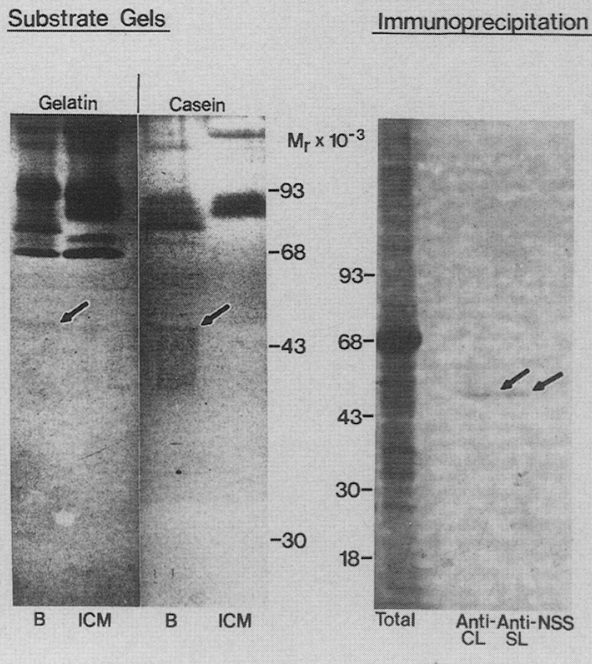

Figure 1. (A) Proteinases are secreted by preimplantation mouse embryos. Proteinases secreted by mouse embryos are detectable by gelatin and casein SDS-substrate gel zymography. The gelatin zymograms (10\% polyacrylamide) were developed for $24 \mathrm{hr}$ and the casein zymograms for $48 \mathrm{hr}$. Each lane contains the proteins secreted into serum-free medium in $48 \mathrm{hr}$ by 32 eggs or embryos: unfertilized eggs (mature ovulated oocytes) (lane $E$ ), one-cell embryos (lane 1), two-cell embryos (lane 2), morulae (lane $M$ ), blastocysts (lane $B$ ), zonae pellucidae isolated from early blastocysts (lane $Z$ ), or ICMs isolated from late blastocysts by immunosurgery (lane $I C M$ ), as well as the proteins secreted by $\mathrm{x}$-irradiated ICMs (lane ICM-X), which do not regenerate primitive endoderm, blastocysts cultured for 4 days to produce outgrowths that contained both trophoblast and endodermal derivatives (lane $O u$ ), and $\mathrm{x}$-irradiated blastocysts cultured for 4 days to produce outgrowths that contained only trophoblast cells (lane $\mathrm{Ou}-\mathrm{X}$ ). $\mathrm{A}$ also shows the proteinases secreted in $4 \mathrm{hr}$ by one egg cylinder-stage (7.5-d.g.) embryo (lane 7.5d). The proteinases secreted by A23187-stimulated rabbit synovial fibroblasts (lane RSF) are shown for comparison. Molecular weight standards $\left(\times 10^{-3}\right)$, procollagenase (proCL), collagenase (CL), prostromelysin (proSL), stromelysin (SL), and $68 \mathrm{kD}$ gelatinase (GL) are shown on the left. The arrows on the right indicate the migration of embryonic proteinases. The gels are printed as negative images for clarity. $(B)$ Proteinases secreted by mouse embryos are metalloproteinases. Proteinases secreted into serum-free medium by inner cell masses (lane ICM), 4-day blastocyst outgrowths (lane $\mathrm{Ou}$ ), and endodermally differentiated PSA-1 and F9 cells (lanes PSA-1 and F9) were separated on SDS-gelatin gels. The zymograms were then developed for $24 \mathrm{hr}$ in control substrate buffer or substrate buffer containing $10 \mu \mathrm{g} / \mathrm{ml}$ recombinant TIMP. (C) Immunoreactive collagenase and stromelysin are synthesized and secreted by mouse blastocysts. (Left) Gelatin and casein substrate (12\% polyacrylamide) gels were used to analyze the proteinases secreted by 100 blastocysts (lane $B$ ) or ICMs (lane ICM) in 48 hr. Note the proteolytic bands in the blastocyst CM migrating at $\sim 50 \mathrm{kD}$ (arrows). (Right) Immunoprecipitation of biosynthetically labeled collagenase and stromelysin secreted by 200 blastocysts in $4 \mathrm{hr}$. Mouse blastocysts were labeled biosynthetically with [ $\left.{ }^{35} \mathrm{~S}\right] \mathrm{methionine}$ for 4 hr. The total secreted proteins (lane Total) and secreted proteins from 200 blastocysts immunoprecipitated by IgG isolated from anticollagenase (lane Anti-CL), antistromelysin (lane Anti-SL), and nonimmune sheep sera (lane NSS) were separated on a 7-15\% SDS-polyacrylamide gradient gel and then fluorographed for 3 weeks. The immunoprecipitated bands are indicated by arrows. 
functional embryonic proteolytic enzymes are metalloproteinases (Fig. 1B). Phenylmethylsulfonyl fluoride (PMSF), an inhibitor of serine proteinases such as plasmin and plasminogen activator, has no effect on the embryonic proteinases.

\section{Blastocysts secrete immunoreactive collagenase and stromelysin}

The observation that a weak $\sim 50-\mathrm{kD}$ gelatinase comigrating with rabbit procollagenase and a $\sim 51-\mathrm{kD}$ caseinase (Fig. 1C) comigrating with rabbit prostromelysin (Fig. 1A) are secreted by blastocysts suggests that embryos may secrete collagenase and stromelysin. Thus, we sought direct evidence for secretion of specific metalloproteinases by embryos. Biosynthetically labeled polypeptide bands of 53 and $52 \mathrm{kD}$ comigrating with rabbit procollagenase and prostromelysin were immunoprecipitated from blastocyst secretions by heterologous antisera specific for collagenase and stromelysin, respectively (Fig. 1C). Qualitatively similar results were obtained in two independent experiments. These data indicate that proteins with immunologically cross-reactive epitopes shared by procollagenase and prostromelysin are synthesized and secreted by blastocysts.

\section{ICM-like embryonal carcinoma cells show altered secretion of proteinases with differentiation}

Shortly after differentiation of ICM and trophectoderm, the ICM gives rise to the primitive endoderm cells that are progenitors of all the extraembryonic (yolk sac and parietal) endoderm. To investigate the proteinases secreted along with ECM molecules during differentiation of ICM to endoderm, we used two lines of embryonal carcinoma cells (F9 and PSA-1) that have an ICM-like phenotype and can be induced to differentiate in culture to form cells that morphologically and biochemically resemble the parietal endoderm, one of the first differentiated derivatives of the ICM. The F9 and PSA-1 cells secreted many proteinases. Several of these proteinases, like the $68-\mathrm{kD}$ gelatinase, were secreted constitutively, whereas differentiation of these cultures to endoderm was associated with an increased secretion of several gelatinases and caseinases, including enzymes that comigrated with rabbit procollagenase and prostromelysin (Fig. 2A). Another embryonal carcinoma cell line, C3HNE, spontaneously differentiates in culture to form cystic bodies that have trophectodermal characteristics (Damjanov and Damjanov 1985). These cells also showed an increase in proteinase activity upon differentiation, and the major gelatinases that they secreted (Fig. 2A) comigrated with those secreted by blastocyst outgrowths and egg cylinder-stage embryos (Fig. 1A).

All of the gelatinases produced by embryonal carcinoma cell lines were inhibited by TIMP (Fig. 1B) and by the chelators 1,10-phenanthroline and EDTA, which inhibit metalloproteinases (Fig. 2B), but not by PMSF or leupeptin, which inhibit serine proteinases/data not shown).

\section{Metalloproteinase and TIMP gene expression is regulated during endoderm differentiation}

RNA from undifferentiated and endodermally differentiated PSA-1 and F9 cells was then analyzed by RNA blotting analysis (Fig. 2C). Although actin mRNA concentration changed during differentiation, the $2-\mathrm{kb}$ collagenase mRNA band seen by blotting with mouse collagenase cDNA at high stringency was regulated developmentally, whereas a $1.9-\mathrm{kb}$ stromelysin mRNA band increased only slightly, relative to actin. A $1-\mathrm{kb}$ TIMP mRNA band increased with endoderm differentiation. The endoderm differentiation was shown by the induction of mRNA for tissue-type PA $(\mathrm{tPA})$, as described previously (Rickles et al. 1988). In contrast, the mRNA for the $68-\mathrm{kD}$ gelatinase/type IV collagenase that appeared to be secreted constitutively (Fig. 2A) did not increase with endoderm differentiation (Fig. 2C).

\section{Stromelysin, collagenase, and TIMP are detectable as} maternal and zygotic mRNA transcripts

Next we used the mRNA phenotyping procedure (Rappolee et al. 1988a,b, 1989) to identify mRNA transcripts for collagenase, stromelysin, and TIMP in preimplantation mouse embryos. This method couples reverse transcription (RT) of purified RNA with enzymatic amplification of cDNA specific sequences by the polymerase chain reaction (PCR), using the thermostable DNA polymerase from Thermus aquaticus (Taq). The PCR reaction is primed by a pair of specific oligonucleotides that span a 200- to 300-bp region of the designated mRNA sequence. The structure of the amplified fragments used for RT-PCR of the metalloproteinases and TIMP is shown in Figure 3A. Because the oligonucleotides for collagenase and stromelysin are not derived from mouse sequences, first we verified that the procedure gave the correct amplified cDNA fragments for RNA isolated from phorbol ester-stimulated rabbit synovial fibroblasts (Fig. 3B). The RT-PCR analysis also gave amplified fragments for collagenase, stromelysin, and TIMP transcripts when RNA was isolated from endodermally differentiated F9 cells. The stromelysin and TIMP transcripts were detected in as little as 1 pg of total F9 RNA with these primers; however, the collagenase oligonucleotide primers were considerably less sensitive than the stromelysin primers with rabbit RNA, and even less sensitive with mouse RNA, based on equivalent secreted collagenase activity; a visible ethidium bromide PCR signal required at least 1-10 ng of F9 RNA. The sensitivity of detection was increased by Southern blotting analysis of the PCR products. To demonstrate that the RT-PCR gives direct qualitative information about mRNA abundance, we showed that collagenase mRNA transcripts are induced in PSA-1 cells during endoderm differentiation (Fig. 3C). The RT-PCR analysis confirms the RNA blotting data showing that endodermally differentiated embryonal carcinoma cells express mRNA transcripts for collagenase, stromelysin, and TIMP (Fig. 2C).

We then analyzed RNA isolated from uncultured mouse embryos. RT-PCR products for stromelysin and 


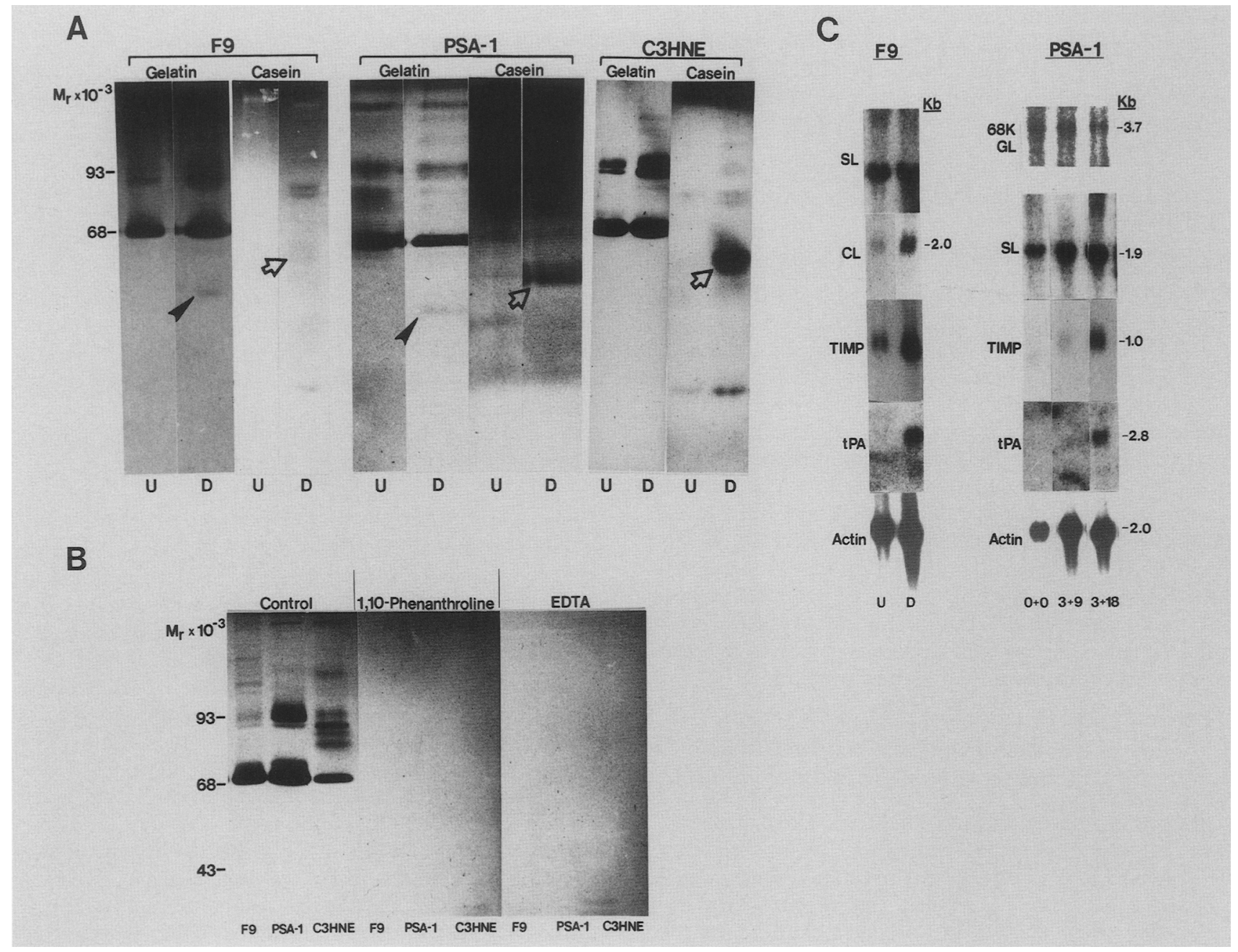

Figure 2. Metalloproteinases and TIMP are regulated during endoderm differentiation. $(A \mid$ Gelatin and casein substrate gels of proteinases secreted by undifferentiated (lane $U$ ) and endodermally differentiated (lane $D)$ F9 and PSA-1 $(3+18)$ cell cultures and by undifferentiated (lane $U$ ) and differentiated (lane $D$ ) trophectoderm-like C3HNE cells. Each lane contains the proteinases secreted by $\sim 10^{4}$ cells in $24 \mathrm{hr}$. The bands comigrating with procollagenase (arrowhead) and prostromelysin (arrow) are indicated. (B) In a separate experiment, proteinases secreted in $24 \mathrm{hr}$ by differentiated F9, PSA-1, and C3HNE cells were separated on SDS-gelatin gels, and the gels were then developed for $24 \mathrm{hr}$ in control substrate buffer or substrate buffer containing $1 \mathrm{~mm}$ 1,10-phenanthroline or 5 mM EDTA. (C) RNA blotting analysis indicates that metalloproteinases and TIMP are regulated during endoderm differentiation. Total RNA (10 $\mu \mathrm{g}$, normalized to ethidium bromide-stained rRNA bands) from undifferentiated (lane $U$ ) and endodermally differentiated (lane $D$ ) F9 and undifferentiated (lane $0+0$ ) and differentiated (lanes $3+9$ and $3+18$ ) PSA-1 cultures was separated on agarose gels, transferred to nylon membranes, and then hybridized with ${ }^{32}$ P-labeled cDNA probes for mouse collagenase (CL), rat stromelysin (SL), mouse TIMP, human $68-\mathrm{kD}$ gelatinase $(68 \mathrm{~K} \mathrm{GL})$, mouse tissue plasminogen activator (tPA), and chicken actin.

TIMP derived from the embryo RNA were readily visible by ethidium bromide staining (Fig. 3D). A very weak ethidium bromide-staining PCR signal for collagenase was observed only for blastocyst-stage embryos after 60 cycles of PCR (data not shown); however, the collagenase PCR products were detected readily after Southern blotting (Fig. 3D). In some experiments two PCR products were seen after amplification of the mouse embryo and embryonal carcinoma cell line RNA. It is likely that the larger fragment is incompletely or alternatively spliced collagenase mRNA. Maternal mRNA transcripts for stromelysin, collagenase, and
TIMP were present in the unfertilized egg (Fig. 3D), and RNA was detectable in the two-cell and eight-cell stages, and abundant at the blastocyst stage. These data suggest that some of the mRNA transcripts for stromelysin, collagenase, and TIMP survive the breakdown of the majority of maternal mRNA species that occurs after fertilization (Schultz 1986), and then are present throughout preimplantation embryonic development as maternal and/or zygotic transcripts. Although stromelysin and collagenase protein were clearly demonstrable by the SDS-substrate gels and immunoprecipitation only at the blastocyst stage, when there was an increase 
A
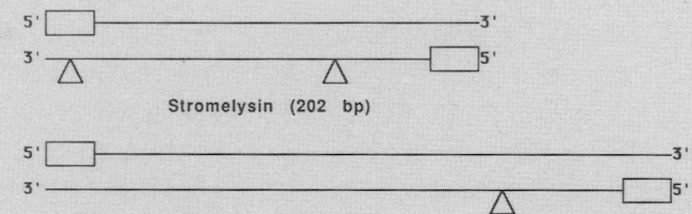

Coliagenase $(301 \mathrm{bp})$

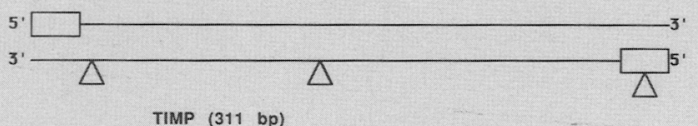

B<smiles>[R]C</smiles>

RSF

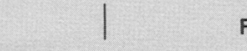

$301=$

202-
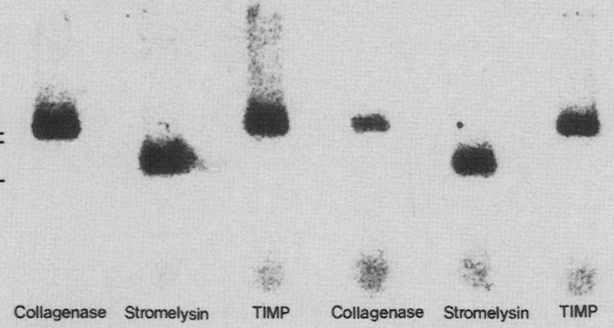

C

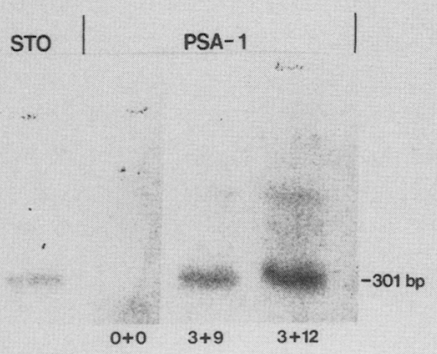

D

Ethidium Bromide

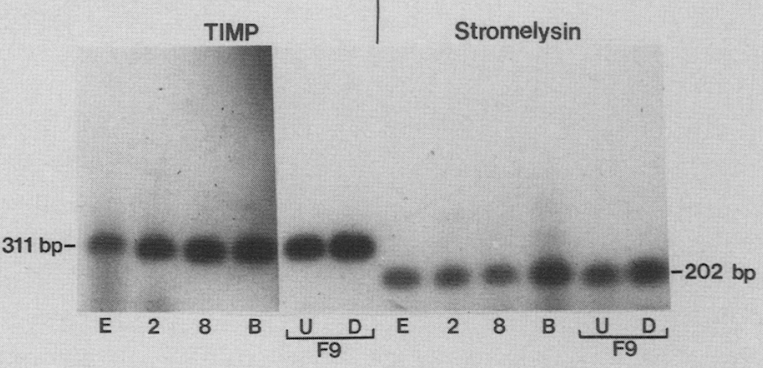

Southern Blot

TIMP

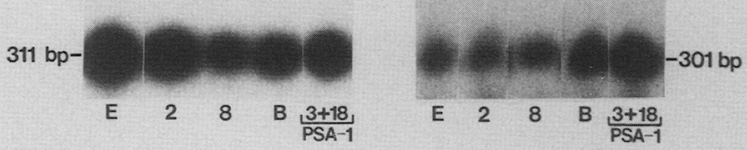

E

\section{Stromelysin}

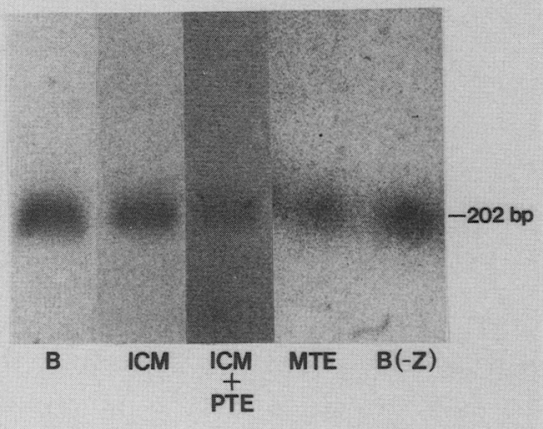

Figure 3. mRNA phenotyping analysis of developing mouse embryos. (A) Design of the oligonucleotides used in the RT-PCR. The introns are shown as triangles, and the oligonucleotides are indicated as boxes. $(B)$ Authentic predicted PCR fragments for collagenase, stromelysin, and TIMP are obtained after RT and 60 cycles of PCR of $100 \mathrm{ng}$ of RNA from phorbol ester-stimulated rabbit synovial fibroblasts (RSF) and from F9 cells endodermally differentiated for 6 days. PCR fragments were separated on agarose gels and then stained with ethidium bromide. The gels are presented as negative images for clarity. $\{C\rangle$ Collagenase mRNA transcripts are induced in PSA-1 cells during endoderm differentiation. RNA (100 ng) obtained from the STO fibroblast feeder layer, from undifferentiated PSA- 1 cells (lane $0+0$, and from PSA-1 cells removed from feeder layers for 3 days, then grown as embryoid bodies for 9 days (lane $3+9$ ) or 12 days (lane $3+12$ ), was reverse-transcribed and the cDNA was amplified for 60 cycles of PCR. (D) Stromelysin, TIMP, and collagenase mRNA transcripts are expressed during preimplantation mouse development. (Top) TIMP and stromelysin RT-PCR fragments were analyzed by ethidium bromide staining. RNA derived from the equivalent of 4.0 unfertilized eggs (mature oocytes) (lane $E$ ), 8.8 two-cell zygotes (lane 2), 4.4 eight-cell zygotes (lane 8), and 4.4 blastocysts (lane $B$ ) was used in each analysis. RNAs from undifferentiated (lane $U$ ) and differentiated (lane $D$ ) F9 cells were used as positive controls. The embryonic RNA was reverse-transcribed into cDNA and then amplified for 60 cycles of PCR. The specific fragments amplified by PCR were separated on agarose gels and then stained with ethidium bromide. (Bottom) TIMP and collagenase RT-PCR fragments were analyzed by Southern blotting. RNA from the equivalent of 3.5 unfertilized eggs (lane E), 4.5 two-cell zygotes (lane 2), 5.2 eight-cell zygotes (lane 8 ), and 3.7 blastocysts (lane $B$ ) was used for RT-PCR. RNA from differentiated PSA- 1 cells (lane $3+18$ ) was used as a control. The PCR fragments were separated on agarose gels, transferred to nylon membranes, and then hybridized with ${ }^{32}$ P-labeled rabbit collagenase or mouse TIMP cDNA probes. $(E)$ Stromelysin mRNA transcripts are expressed in both ICM and trophectoderm. RNA was derived from the equivalent of five immunosurgically isolated ICMs (lane ICM), 6.3 ICM plus polar trophectoderm (lane ICM $+P T E$ ) equivalents dissected from blastocysts, 2.3 mural trophectoderm (lane $M T E$ ) equivalents dissected from blastocysts, and 3.7 whole blastocyst equivalents (lane $B$ ) either with or without (lane $-Z$ ) zonae pellucidae. The RNA was reverse-transcribed, the resulting cDNA was amplified for 60 cycles of PCR, and fragments were analyzed by ethidium bromide staining. 
in their RNA transcripts, the RT-PCR procedure is considerably more sensitive; therefore, it was not surprising to see mRNA at earlier stages than enzyme.

We then validated the PCR reaction products by DNA sequencing. The sequence of the PCR cDNA fragment of mouse embryonic TIMP (data not shown) had a 1-bp difference from the published sequence /Gewert et al. 1987). Two stromelysin cDNA sequences were found in individual clones of the amplified fragments (Fig. 4). The predicted sequence of the amplified fragment of embryonic mouse stromelysin (EMS-1) is more closely related to rat transin-1, the rat version of stromelysin (Matrisian et al. 1985), with a $96 \%$ amino acid conservation, than to rat transin-2, another member of the stromelysin family (Breathnach et al. 1987), with $72 \%$ amino acid conservation. EMS- 2 has $85 \%$ amino acid homology and $90 \%$ nucleic acid homology with EMS-1 but is no more closely related to rat transin-2 than is EMS-1. EMS- 1 has $77 \%$ amino acid homology with both human (Wilhelm et al. 1987) and rabbit (Fini et al. 1987) stromelysins, and EMS-2 has $83 \%$ and $79 \%$ homology with human and rabbit stromelysins, respectively. At the amino acid level, EMS- 2 is identical to an uncharacterized metalloproteinase cDNA isolated recently from a mouse tumor (Ostrowski et al. 1988). Digestion of the mouse stromelysin cDNA by restriction endonucleases suggests that EMS-2 is present in greater abundance than EMS-1 (data not shown|.

\section{Stromelysin transcripts are expressed in both ICM and trophectoderm of the blastocyst}

The detection of functional proteinases by SDS-substrate gel zymography (Fig. 1) suggested that trophectoderm and ICM produce different metalloproteinases. Because the trophectoderm cells are responsible for placental invasiveness during implantation, it was of particular interest to determine whether any specific metalloproteinase transcripts are localized to the trophectoderm-specific region of the embryo. ICM separated from trophectoderm by immunosurgery (Solter and Knowles 1975), ICM with overlying polar trophectoderm, and pure mural trophectoderm separated by manual dissection were used for mRNA phenotyping analysis. Stromelysin transcripts were detectable in all of these samples (Fig. 3E), demonstrating that both ICM and trophectoderm lineages produce this metalloproteinase.

\section{Discussion}

We have provided direct evidence that the genes encoding secreted metalloproteinases are expressed during peri-implantation development in mouse embryos. The 68-kD gelatinase/type IV collagenase is secreted by the unfertilized and one-cell embryo, disappears by the fourcell stage, and reappears by the blastocyst stage. Secretion of this proteinase rapidly increases with blastocyst outgrowth, implantation, and development to the egg cylinder stage. Other gelatinases and caseinases appear at the blastocyst and blastocyst outgrowth stages. Two well-characterized metalloproteinases, collagenase and stromelysin, are secreted at the blastocyst stage. Using RNA phenotyping analysis (Rappolee et al. 1988a,b, 1989|, we found that TIMP, collagenase, and stromelysin are present as maternal transcripts in the unfertilized egg and then are largely retained during the breakdown of the majority of maternal transcripts at the two-cell stage. The exact time of initiation of transcription of metalloproteinase and TIMP genes in the zygote is, therefore, unclear. However, an overall increase in mRNA is evident at the blastocyst stage, when collagenase, stromelysin, and gelatinase secretion increases dramatically, and when increased synthesis of ECM and cell migration are taking place.

The observation that oocytes, ICM, and trophoblast all secrete proteinases, but have distinct patterns of these enzymes, also suggests tissue-specific functions. These data suggest a role for these gene products in oogenesis or ovulation and in the early embryo when cellcell and cell-ECM interactions first take place (Sutherland et al. 1988). In contrast to the observations on mRNA transcripts for the metalloproteinases and TIMP, tPA mRNA disappears at the two-cell stage and is not transcribed again until late in the differentiation of parietal endoderm several days after implantation (Strickland et al. 1976, 1988; Rickles et al. 1988). Platelet-derived growth factor-A (PDGF-A) and transforming growth factor- $\alpha$ (TGF- $\alpha$ ) also are found as maternal transcripts and then disappear and reappear during the cleavage stages in early mammalian development, and TGF- $\beta 1$ appears only after zygotic transcription begins (Rappolee et al. 1988a). These growth factors increase at the blastocyst stage, the same time as the increase in collagenase, stromelysin, and TIMP transcripts (Rappolee et al. 1988a). A possible important interaction is that these growth regulatory factors can regulate expression of proteinases and TIMP (Edwards et al. 1987). It will be interesting to determine whether embryonic cells regulate inhibitors and proteinases through production of growth factors.

Our data point to a role for the metalloproteinases in ECM remodeling from the first phases of embryonic cell-ECM contacts. There is also evidence supporting a role of ECM degradation later in embryogenesis. During sea urchin gastrulation, continuous remodeling of collagen within the blastocoelic matrix (Wessel and McClay 1987) suggests the presence of a collagenolytic enzyme. Metalloproteinases and PA also have been observed in other developmental processes, including growing and remodeling of bone (Sellers et al. 1978; Dean et al. 1985), tadpole tail resorption (Gross and Bruschi 1971), neurite extension (Pittman 1985; Valinsky and Le Douarin 1985), endothelial cell migration (Pepper et al. 1987; Saksela et al. 1987), branching morphogenesis (Nakanishi et al. 1986), mammary gland development and involution (Ossowski et al. 1979; Unemori et al. 1987), transformation (Collier et al. 1988; Khokha et al. 1989), and ovulation (Canipari et al. 1987). Urokinase-type PA production by trophoblast cells par- 
A

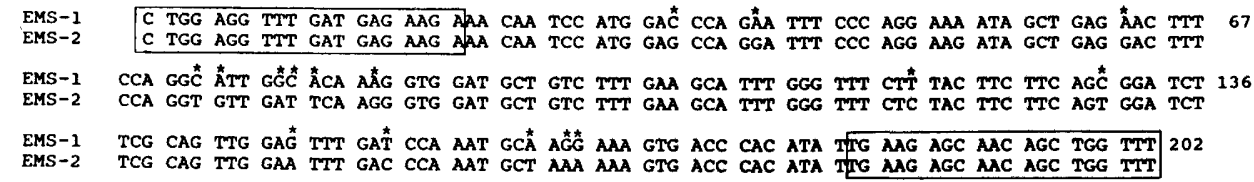

B

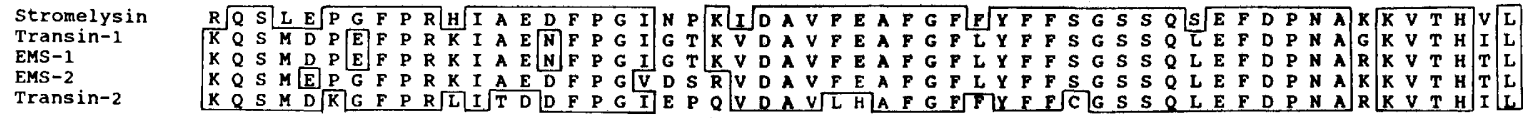

Figure 4. Mouse embryos express two stromelysin RNA transcripts, EMS-1 and EMS-2. (A) DNA sequence of EMS-1 and EMS-2 PCR fragments derived from RT-PCR of mouse blastocyst RNA. The asterisks show the differences between the two sequences. The boxes indicate the oligonucleotide primers. $(B)$ Deduced amino acid sequences of EMS-1 and EMS-2 compared to rat transin-1 and transin-2 and rabbit stromelysin. The common sequences are boxed. Only the sequences between the oligonucleotide primers are shown.

allels the invasive phase of their life cycle (Strickland et al. 1976).

For direct demonstration of a critical role of the metalloproteinases in development, it is necessary to modify development by modifying proteinase function. In preliminary experiments we have observed that TIMP modulates peri-implantation development of mouse embryos in culture, and this underscores the functions of the metalloproteinases in development (Behrendtsen et al. 1988). Surprisingly, TIMP stimulates the migration of parietal endoderm-like cells from the blastocyst outgrowths. TIMP also stimulates supernumerary budding in branching morphogenesis (Nakanishi et al. 1986), a process that requires both ECM stabilization and degradation, as well as cell migration and proliferation. It is interesting to note that the glial-derived neurite-outgrowth factor is also a proteinase inhibitor (Gloor et al. 1986). Although ECM components such as fibronectin facilitate morphogenetic movements during embryogenesis (Critchley et al. 1979), and interference with cell-ECM adhesion inhibits migration during embryogenesis (Boucaut et al. 1984), proteinases also are produced by migrating cells (Pittman 1985; Valinsky and Le Douarin 1985; Pepper et al. 1987). These data suggest that regulation of proteolysis of ECM components may be a critical step in facilitating and regulating cell migration and/or proliferation. It should be feasible to use molecular approaches such as transgenesis and homologous recombination for deleting genes or overexpressing them in mouse embryos to enhance our knowledge of the biological functions of these ECM-degrading enzymes.

\section{Experimental procedures}

\section{Materials}

Taq polymerase was obtained from Perkin-Elmer Cetus. Restriction enzymes were obtained from New England Biolabs and Bethesda Research Labs. Radioisotopes were purchased from Amersham. Moloney murine leukemia virus (Mo-MLV) reverse transcriptase was purchased from BRL or BoehringerMannheim. Mice were purchased from Jackson Labs and
Harlan Sprague-Dawley. Oligo(dT) primers for reverse transcription were obtained from Pharmacia. Oligonucleotide primers for PCR were synthesized by the UCSF Biomolecular Resource Center. Polyclonal sheep anti-collagenase (Hembry et al. 1986; Werb et al. 1986) and sheep anti-stromelysin (Werb et al. 1986) were a gift of G. Murphy (Strangeways Research Laboratory, Cambridge, UK). Recombinant human TIMP was a gift of D. Carmichael, Synergen Corporation, Boulder, Colorado.

\section{Mouse eggs and embryos}

Standard techniques were used for obtaining eggs and zygotes (Hogan et al. 1986). Female CF-1 mice (25-30 grams, Harlan Sprague-Dawley) were injected with 10 IU of pregnant mares' serum (Sigma) followed by an injection of $5 \mathrm{IU}$ of human chorionic gonadotropin (HCG, Organon) $48 \mathrm{hr}$ later. To obtain embryos, female mice were housed overnight with $F_{1}$ hybrid males (C57BL/6J females $\times$ SJL/J males, Jackson Labs) immediately after injection of HCG. Embryos were obtained at the following stages: one-cell (24 hr after HCG), two-cell (48 hr after HCG), eight-cell (65 hr after HCG), early blastocyst ( $96 \mathrm{hr}$ after HCG), and late blastocyst (120 hr after HCG). Egg cylinder-stage embryos were dissected from the uteri of mice 7.5 days after injection of HCG. Embryos were flushed from oviducts or uteri with flushing medium-I (FM-I) (Spindle 1980) plus $6 \mathrm{mg} / \mathrm{ml}$ of bovine serum albumin (BSA). The embryos were then washed through three drops of fresh FM-I + BSA. Unfertilized eggs (mature oocytes) were dissected from oviducts $14 \mathrm{hr}$ after injection of HCG and treated with hyaluronidase to remove adherent cumulus cells. Eggs and embryos were examined under a dissecting microscope to ensure that no contaminating maternal cells were present.

\section{Embryo culture}

For each analysis 100-200 embryos/stage were cultured for 48 $\mathrm{hr}$ in $50 \mu \mathrm{l}$ of Dulbecco's modified Eagle's medium (DME) containing $0.2 \%$ lactalbumin hydrolysate $(\mathrm{LH})$ in microdrops, which were covered with paraffin oil (Aldrich) to prevent evaporation. All experiments were performed at least three times.

Blastocyst outgrowths were made by culturing hatched blastocysts on gelatin-coated wells of 96-well microliter plates for $24-48 \mathrm{hr}$ at $37^{\circ} \mathrm{C}$ in $100 \mu \mathrm{l}$ of DME and $10 \%$ fetal bovine serum (FBS). To prepare serum-free conditioned medium for SDSsubstrate gel analysis, the medium containing FBS was replaced with $50 \mu \mathrm{l}$ of DME-LH, and the outgrowths were cultured for an additional $24-48 \mathrm{hr}$. 
Trophoblast outgrowths devoid of ICM cells were obtained by x-irradiating early blastocysts with $10 \mathrm{~Gy}$ (Goldstein et al. 1975 ) and then culturing them for 3-4 days as described for whole blastocyst outgrowths.

ICMs were obtained by immunosurgery (Solter and Knowles 1975). Blastocysts were incubated for $15 \mathrm{~min}$ at $37^{\circ} \mathrm{C}$ in a rabbit anti-mouse L-cell IgG (Wiley et al. 1978), washed three times in FM-I + BSA, and then incubated for $40 \mathrm{~min}$ at $37^{\circ} \mathrm{C}$ in guinea pig complement (Sigma) to lyse the trophectoderm cells. The dead trophectoderm cells were removed by rapid pipetting. Blastocyst fragments consisting of pure mural trophectoderm or polar trophectoderm plus ICM were obtained by manually dissecting zona-free expanded blastocysts with fine glass needles in FM-I on a cushion of $2 \%$ agar.

\section{Biosynthetic labeling and immunoprecipitation of blastocyst proteins}

Six hundred blastocysts were incubated for $4 \mathrm{hr}$ in $300 \mu \mathrm{l}$ of TE medium containing $1 \mathrm{mCi} / \mathrm{ml}$ of $\left[{ }^{35} \mathrm{~S}\right]$ methionine $(2000 \mathrm{Ci} /$ mmole, Amersham). At the end of the labeling period, the conditioned culture medium was collected, and secreted proteins were immunoprecipitated from $100-\mu l$ aliquots by sheep antirabbit collagenase IgG, sheep anti-rabbit stromelysin IgG, or nonimmune sheep IgG, followed by protein A-Sepharose. These samples were then separated by SDS-polyacrylamide gel electrophoresis. The experiments were performed twice.

\section{Cell culture}

The following embryonal carcinoma cell lines were used: F9 cells, obtained from the University of California, San Francisco, Cell Culture Facility; PSA-1 and STO fibroblasts, obtained from G. Martin, University of California, San Francisco; and C3HNE cells, obtained from I. Damjanov (Wistar Institute). F9 cells were cultured on gelatin (Sigma)-coated culture dishes in DME containing $10 \%$ heat-inactivated FBS. STO fibroblasts were maintained in either DME containing $10 \%$ calf serum (Gibco) or DME containing 5\% FBS and 5\% calf serum. C3HNE cells were cultured in RPMI medium (Gibco) containing $10 \%$ FBS. C3HNE trophoblast vesicles were collected by shaking off confluent cultures (Damjanov and Damjanov 1985). PSA-1 cells were maintained on a confluent feeder layer of $x$-irradiated STO fibroblasts in DME containing $10 \%$ calf senum. To collect conditioned medium for SDS-substrate gel analysis, the confluent cell cultures were incubated in serum-free medium for $24 \mathrm{hr}$. Rabbit synovial fibroblasts were cultured and stimulated to secrete proteinases as described previously (Unemori and Werb 1988).

\section{Endoderm differentiation of F9 and PSA-1 cells}

F9 cells $\left(5 \times 10^{5}\right)$, which resemble undifferentiated ICM cells, were seeded onto gelatin-coated $10-\mathrm{cm}$ tissue culture dishes and cultured for up to 6 days with $5 \times 10^{-7} \mathrm{M}$ retinoic acid, $10^{-4} \mathrm{M}$ dibutyryl cAMP, and $5 \mathrm{mM}$ isobutylmethylxanthine in DME containing $10 \%$ calf serum (Strickland and Mahdavi 1978; Solter et al. 1979; Hogan et al. 1981) to obtain cells that resemble the parietal endoderm, which are progeny cells of the primitive endoderm (Strickland et al. 1976, 1980; Hogan et al. 1986).

Undifferentiated PSA-1 cells were removed from $\mathbf{x}$-irradiated STO fibroblast feeder layers and designated $0+0$. To obtain endodermally differentiated cultures (Martin et al. 1977), PSA-1 cells were removed from the feeder layers for 3 days and then cultured in suspension as embryoid bodies in bacteriological culture dishes for up to 18 days (designated $3+$ [number of days]). These experiments were performed at least twice.

\section{Zymography of proteinases on SDS-substrate gels}

To determine whether ECM-degrading proteinases were secreted during mouse embryogenesis, embryos, embryonal tissues, and embryonal carcinoma cells were cultured separately for 24 or $48 \mathrm{hr}$ in DME-LH or RPMI-LH. The conditioned medium was then analyzed by zymography, as described previously (Herron et al. 1986b; Unemori and Werb 1986). Conditioned medium $(5-20 \mu l)$ was diluted with $4 \times$ SDS sample buffer without 2 -mercaptoethanol, and then loaded onto $10 \%$ or $12 \%$ SDS-polyacrylamide gels containing $1 \mathrm{mg} / \mathrm{ml}$ of either gelatin or casein. After electrophoresis these gels were washed twice for $15 \mathrm{~min}$ in $2.5 \%$ Triton X-100 (Sigma) and incubated for 24 to $48 \mathrm{hr}$ at $37^{\circ} \mathrm{C}$ in $350 \mathrm{~mm}$ Tris- $\mathrm{HCl}$ buffer $(\mathrm{pH} \mathrm{7.6),}$ containing $10 \mathrm{mM} \mathrm{CaCl}_{2}$. Gels were then stained in Coomassie Blue R250, followed by destaining. Clear bands indicate the presence of proteolytic enzymes. The photographs of the gels are printed as negative images for clarity.

\section{RNA preparation}

A microadaptation (Rappolee et al. 1988a,b, 1989) of the guanidine thiocyanate (GuSCN)/CsCl gradient ultracentrifugation procedure (Chirgwin et al. 1979) was used to prepare total RNA from embryos. One to 100 eggs or embryos were washed through six drops of FM-I, added to $100 \mu \mathrm{l}$ of GuSCN solution containing $20 \mu \mathrm{g}$ of Escherichia coli ribosomal RNA as carrier, and then layered over $100 \mu \mathrm{l}$ of $5.7 \mathrm{M} \mathrm{CsCl}$ and centrifuged for $20 \times 10^{6} \mathrm{~g}-\mathrm{min} / \mathrm{cm}$ gradient in the TL-100 rotor of a Beckman TL-IOO bench-top centrifuge. Yields of RNA, determined by reading $A_{260}$, were generally $35-60 \%$. Total RNA used for positive controls and for RNA blotting analysis was prepared by the standard GuSCN/CsCl procedure (Chirgwin et al. 1979) from PSA-1 cells, from F9 cells differentiated as described above, and from rabbit synovial fibroblasts treated with $100 \mathrm{ng} / \mathrm{ml}$ of 12-O-tetradecanoylphorbol-13-acetate for $24 \mathrm{hr}$, as described previously (Frisch et al. 1987). The concentration of RNA was determined by $A_{260}$, and the normalization was checked by running samples on agarose gels and staining the rRNA bands with ethidium bromide.

\section{mRNA phenotyping analysis}

The single-cell mRNA phenotyping analysis, consisting of reverse transcription of mRNA followed by amplification of cDNA fragments by PCR, was performed essentially as described previously (Rappolee et al. 1988a,b, 1989). Briefly, the RNA was reverse-transcribed with Mo-MLV reverse transcriptase and oligo(dT) priming. Reverse transcription was repeated by denaturing at $93^{\circ} \mathrm{C}$, flash-cooling on ice, and reincubating with an additional $50 \mathrm{U}$ of Mo-MLV reverse transcriptase. PCR was performed essentially as described previously (Saiki et al. 1988). A small portion of RT products $\{1 \mu$, stated in the figure legends as the number of embryo-equivalents in that aliquot) was mixed with 1 unit of Taq DNA polymerase and 50 pmoles of the 20- to 25-base-long oligonucleotide $5^{\prime}$ and $3^{\prime}$ sequencespecific primers in a buffer containing $10 \mathrm{mM}$ Tris- $\mathrm{HCl}(\mathrm{pH} 8.3)$, $2.5 \mathrm{mM} \mathrm{MgCl} 2,50 \mathrm{mM} \mathrm{KCl}$, and $5 \mu \mathrm{g}$ of acetylated bovine senum albumin, in a $50-\mu l$ volume. The mixture was overlaid with mineral oil to prevent evaporation and then amplified by PCR in a repeated three-temperature cycle on a Perkin-Elmer Cetus Thermocycler programmable heating block. The PCR fragments were separated on $2-4 \%$ agarose gels and then 
stained with ethidium bromide. The gels were photographed and printed as negative images for clarity. In some experiments the separated PCR fragments were transferred to nylon membranes and hybridized with ${ }^{32} \mathrm{P}-$ labeled cDNA probes. Experiments were performed at least three times with independent embryo preparations.

\section{Oligonucleotides}

Oligonucleotides were designed by the rules outlined by Rappolee et al. (1989). The structures of the oligonucleotides used in this study were designed from known sequences as follows: Stromelysin (Matrisian et al. 1985; Fini et al. 1987; Wilhelm et al. 1987; Frisch et al. 1987; Werb, unpublished sequence of rabbit stromelysin):

5'Oligonucleotide: 5'-CTGGAGGTTTGATGAGAAGA-3' 3'Oligonucleotide: 5'-AAACCAGCTGTTGCTCTTCA-3' Collagenase (Whitham et al. 1986; Frisch et al. 1987; Werb, unpublished sequence of rabbit collagenase):

5'Oligonucleotide: 5'-ACAGCTCCTTTGGCT TCCCT-3' 3'Oligonucleotide: 5'-TTGAACCAGCTATTAGCTTT-3' TIMP (Gewert et al. 1987):

5'Oligonucleotide: 5'-ACCACCTTATACCAGCGTTA-3' 3'Oligonucleotide: 5'-AAACAGGGAAACACTGTGCA-3'

\section{cDNA probes}

The cDNA probes used in this study were obtained from the following sources: rabbit collagenase, pCL1 (Frisch et al. 1987): rabbit stromelysin, pSL2 (Frisch et al. 1987); mouse tPA, gift of R. Rickles (SUNY-Stonybrook; Rickles et al. 1988); chicken actin, pAl, gift of $M$. Kirschner (University of California, San Francisco; Cleveland et al. 1980); rat transin-1, pTR1, gift of R. Breathnach (University of Strasbourg; Matrisian et al. 1985); human stromelysin, gift of G. Goldberg (Washington University, St. Louis; Wilhelm et al. 1987); human 68-kD gelatinase/ type IV collagenase, gift of G. Goldberg (Washington University, St. Louis; Collier et al. 1988); mouse TIMP, gift of B. Williams (University of Toronto; Gewert et al. 1987). For mouse collagenase and mouse stromelysin cDNA, the PCR-amplified fragments derived from F9 or PSA-1 RNA were purified by agarose gel electrophoresis.

\section{DNA sequence analysis}

PCR fragments were purified, phosphorylated, and then ligated into M13 vectors for single-strand sequencing using Sequenase by standard procedures (Church and Gilbert 1984; Tabor and Richardson 1987). At least two independent M13 clones were used to validate each sequence, generally in opposite orientations.

\section{RNA blotting}

RNA isolated from F9 and PSA-1 cells was separated and run on denaturing agarose gels, transferred to nylon membranes by capillary action (Thomas 1980; Reed and Mann 1985), and then UV cross-linked (Lehrach et al. 1977; Church and Gilbert 1984). The RNA was then hybridized with inserts from cDNA clones or PCR-amplified cDNA radiolabeled with [32 P]dCTP by nicktranslation (Maniatis et al. 1982).

\section{Acknowledgments}

We thank Dr. R. Schultz for helping with some of the experiments, Ole Behrendtsen for technical assistance, Susan Brekhus and Rick Lyman for typing the manuscript, and Mary McKenney for editing it. This work was supported by the Office of Health and Environmental Research, U.S. Department of Energy (contract DE-AC03-76-SF01012), by grants from the National Institutes of Health (HD 23539 and HD 23651), and by National Institutes of Health National Research Service Award 5 T32 ES07106 from the National Institute of Environmental Health Sciences.

\section{References}

Adamson, E.D. 1982. The effect of collagen on cell division, cellular differentiation and embryonic development. In Collagen in health and disease (ed. J.B. Weiss and M.I.V. Jayson|, pp. 218-243. Churchill Livingstone, Edinburgh.

Armant, D.R., H.A. Kaplan, and W.J. Lennarz. 1986. Fibronectin and laminin promote in vitro attachment and outgrowth of mouse blastocysts. Dev. Biol. 116: 519-523.

Behrendtsen, O., C.A. Alexander, and Z. Werb. 1988. Tissue inhibitor of metalloproteinases (TIMP) influences development of peri-implantation mouse embryos in culture $/ \mathrm{ab}$ stract). J. Cell Biol. 107: 604a.

Boucaut, J.-C., T. Darribère, T.J. Poole, H. Aoyama, K.M. Yamada, and J.P. Thiery. 1984. Biologically active synthetic peptides as probes of embryonic development: A competitive peptide inhibitor of fibronectin function inhibits gastrulation in amphibian embryos and neural crest cell migration in avian embryos. J. Cell Biol. 99: 1822-1830.

Breathnach, R., L.M. Matrisian, M.-C. Gesnel, A. Staub, and P. Leroy. 1987. Sequences coding for part of oncogene-induced transin are highly conserved in a related rat gene. Nucleic Acids Res. 15: 1139-1151.

Canipari, R., M.L. O'Connell, G. Meyer, and S. Strickland. 1987. Mouse ovarian granulosa cells produce urokinase-type plasminogen activator, whereas the corresponding rat cells produce tissue-type plasminogen activator. I. Cell Biol. 105: $977-981$.

Chin, J.R, G. Murphy, and Z. Werb. 1985. Stromelysin, a connective tissue-degrading metalloendopeptidase secreted by stimulated rabbit synovial fibroblasts in parallel with collagenase. Biosynthesis, isolation, characterization, and substrates. J. Biol. Chem. 260: 12367-12376.

Chirgwin, J.M., A.E. Przybyla, R.J. MacDonald, and W.J. Rutter. 1979. Isolation of biologically active ribonucleic acid from sources enriched in ribonuclease. Biochemistry 18: 52945299.

Church, G.M. and W. Gilbert. 1984. Genomic sequencing. Proc. Natl. Acad. Sci. 81: 1991-1995.

Cleveland, D.W., M.A. Lopata, R.I. McDonald, N.J. Cowan, W.J. Rutter, and M.W. Kirschner. 1980. Number and evolutionary conservation of $\alpha$ - and $\beta$-tubulin and cytoplasmic $\beta$ and $\gamma$-actin genes using specific cloned cDNA probes. Cell 20: 95-105.

Collier, I.E., S.M. Wilhelm, A.Z. Eisen, B.L. Marmer, G.A Grant, J.L. Seltzer, A. Kronberger, C. He, E.A. Bauer, and G.I. Goldberg. 1988. H-ras oncogene-transformed human bronchial epithelial cells (TBE-1) secrete a single metalloprotease capable of degrading basement membrane collagen. J. Biol. Chem. 263: 6579-6587.

Cooper, A.R. and H.A. MacQueen. 1983. Subunits of laminin are differentially synthesized in mouse eggs and early embryos. Dev. Biol. 96: 467-471.

Critchley, D.R., M.A. England, J. Wakely, and R.O. Hynes. 1979. Distribution of fibronectin in the ectoderm of gastrulating chick embryos. Nature 280: 498-500.

Damjanov, I. and A. Damjanov. 1985. Trophectodermal carci- 
noma: Mouse teratocarcinoma-derived tumour stem cells differentiating into trophoblastic and yolk sac elements. $I$. Embryol. Exp. Morphol. 86: 125-141.

Dean, D.D., O.E. Muniz, I. Berman, J.C. Pita, M.R. Carreno, J.F. Woessner, Jr., and D.S. Howell. 1985. Localization of collagenase in the growth plate of rachitic rats. $/$. Clin. Invest. 76: $716-722$.

Edwards, D.R., G. Murphy, J.J. Reynolds, S.E. Whitham, A.J.P. Docherty, P. Angel, and J.K. Heath. 1987. Transforming growth factor-beta modulates the expression of collagenase and metalloproteinase inhibitor. EMBO /. 6: 1899-1904.

Fini, M.E., M.J. Karmilowicz, P.L. Ruby, A.M. Beeman, K.A. Borges, and C.E. Brinckerhoff. 1987. Cloning of a complementary DNA for rabbit proactivator. A metalloproteinase that activates synovial cell collagenase, shares homology with stromelysin and transin, and is coordinately regulated with collagenase. Arth. Rheum. 30: 1254-1264.

Frisch, S.M., E.J. Clark, and Z. Werb. 1987. Coordinate regulation of stromelysin and collagenase genes determined with cDNA probes. Proc. Nat1. Acad. Sci. 84: 2600-2604.

Gavrilovic, J., R.M. Hembry, J.J. Reynolds, and G. Murphy. 1987. Tissue inhibitor of metalloproteinases (TIMP) regulates extracellular type I collagen degradation by chondrocytes and endothelial cells. J. Cell Sci. 87: 357-362.

Gewert, D.R., B. Coulombe, M. Castelino, D. Skup, and B.R.G. Williams. 1987. Characterization and expression of a murine gene homologous to human EPA/TIMP: A virus-induced gene in the mouse. EMBO J. 6: 651-657.

Glass, R.H., J. Aggeler, A. Spindle, R.A. Pedersen, and Z. Werb. 1983. Degradation of extracellular matrix by mouse trophoblast outgrowths: A model for implantation. J. Cell Biol. 96: $1108-1116$.

Gloor, S., K. Odink, J. Guenther, H. Nick, and D. Monard. 1986. A glia-derived neurite promoting factor with protease inhibitory activity belongs to the protease nexins. Cell 47: 687693.

Goldstein, L.S., A.I. Spindle, and R.A. Pedersen. 1975. X-ray sensitivity of the preimplantation mouse embryo in vitro. Radiat. Res. 62: 276-287.

Gross, J. and A.B. Bruschi. 1971. The pattern of collagen degradation in cultured tadpole tissues. Dev. Biol. 26: 36-41.

Hembry, R.M., G. Murphy, T.E. Cawston, J.T. Dingle, and J.J. Reynolds. 1986. Characterization of a specific antiserum for mammalian collagenase from several species: Immunolocalization of collagenase in rabbit chondrocytes and uterus. $I$. Cell Sci. 81: 105-123.

Herron, G.S., M.J. Banda, E.J. Clark, J. Gavrilovic, and Z. Werb. 1986a. Secretion of metalloproteinases by stimulated capillary endothelial cells. II. Expression of collagenase and stromelysin activities is regulated by endogenous inhibitors. $J$. Biol. Chem. 261: 2814-2818.

Herron, G.S, Z. Werb, K. Dwyer, and M.J. Banda. 1986b. Secretion of metalloproteinases by stimulated capillary endothelial cells. I. Production of procollagenase and prostromelysin exceeds expression of proteolytic activity. $J$. Biol. Chem. 261: $2810-2813$.

Hogan, B.L.M., A. Taylor, and E. Adamson. 1981. Cell interactions modulate embryonal carcinoma cell differentiation into parietal or visceral endoderm. Nature 291: 235-237.

Hogan, B., F. Costantini, and E. Lacy. 1986. Manipulating the mouse embryo: A laboratory manual, pp. 89-149. Cold Spring Harbor Laboratory, Cold Spring Harbor, New York.

Huarte, J., D. Belin, A. Vassalii, S. Strickland, and J.D. Vassalli. 1987. Meiotic maturation of moose oocytes triggers the translation and polyadenylation of dormant tissue-type plasminogen activator mRNA. Genes Dev. 1: 1201-1211.
Khokha, R., P. Waterhouse, S. Yagel, P.K. Lala, C.M. Overall, G. Norton, and D.T. Denhardt. 1989. Antisense RNA-induced reduction in murine TIMP levels confers oncogenicity on Swiss 3T3 cells. Science 243: 947-950.

Kubo, H., S. Katayama, H. Amano, and A.I. Spindle. 1982. Plasminogen activator activity in mouse embryos cultured on decidual cell monolayers. Acta Obstet. Gynaecol. Ipn. 34: 801-808.

Lehrach, H., D. Diamond, J.M. Wozney, and H. Boedtker. 1977. RNA molecular weight determinations by gel electrophoresis under denaturing conditions, a critical reexamination. Biochemistry 16: 4743-4751.

Maniatis, T., E. Fritsch, and J. Sambrook. 1982. Molecular cloning: A laboratory manual. Cold Spring Harbor Laboratory, Cold Spring Harbor, New York.

Martin, G.R., L.M. Wiley, and I. Damjanov. 1977. The development of cystic embryoid bodies in vitro from clonal teratocarcinoma cells. Dev. Biol. 61: 230-244.

Matrisian, L.M., N. Glaichenhaus, M.-C. Gesnel, and R. Breathnach. 1985. Epidermal growth factor and oncogenes induce transcription of the same cellular mRNA in rat fibroblasts. EMBO J. 4: 1435-1440.

Mignatti, P., E. Robbins, and D.B. Rifkin. 1986. Tumor invasion through the human amniotic membrane: Requirement for a proteinase cascade. Cell 47: 487-498.

Murphy, G. and J.J. Reynolds. 1985. Current views of collagen degradation: Progress towards understanding the resorption of connective tissues. Bioessays 2: 55-60.

Murphy, G., J.J. Reynolds, and Z. Werb. 1985. Biosynthesis of tissue inhibitor of metalloproteinases by human fibroblasts in culture: Stimulation by 12-O-tetradecanoylphorbol 13-acetate and interleukin 1 in parallel with collagenase. J. Biol. Chem. 260: 3079-3083.

Nakanishi, Y., F. Sugiura, J.-I. Kishi, and T. Hayakawa. 1986. Collagenase inhibitor stimulates cleft formation during early morphogenesis of mouse salivary gland. Dev. Biol. 113: 201-206.

Ossowski, L., D. Biegel, and E. Reich. 1979. Mammary plasminogen activator: Correlation with involution, hormonal modulation and comparison between normal and neoplastic tissue. Cell 16: 929-940.

Ostrowski, L.R., J. Finch, P. Krieg, L. Matrisian, G. Patskan, J.F. O'Connell, J. Philips, T.J. Slaga, R. Breathnach, and G.T. Bowden. 1988. Expression pattern of a gene for a secreted metalloproteinase during late stages of tumor progression. Mol. Carcinogen. 1: 13-19.

Pedersen, R.A. 1988. Early mammalian embryogenesis. In The physiology of reproduction, (ed. E. Knobil and J. Neill), pp. 187-230. Raven Press, New York.

Pepper, M.S., J.-D. Vassalli, R. Montesano, and L. Orci. 1987. Urokinase-type plasminogen activator is induced in migrating capillary endothelial cells. $f$. Cell Biol. 105: 25352541.

Pittman, R.N. 1985. Release of plasminogen activator and calcium-dependent metalloproteinases from cultured sympathetic and sensory neurons. Dev. Biol. 110: 91-101.

Rappolee, D.A., C.A. Brenner, R Schulz, D. Mark, and Z. Werb. 1988a. Developmental expression of PDGF, TGF- $\alpha$, and TGF- $\beta$ genes in preimplantation mouse embryos. Science 241: $1823-1825$.

Rappolee, D.A., D. Mark, M.J. Banda, and Z. Werb. 1988b. Wound macrophages express TGF- $\alpha$ and other growth factors in vivo: Analysis by mRNA phenotyping. Science 241: 708-712.

Rappolee, D.A., A. Wang, D. Mark, and Z. Werb. 1989. A novel method for studying mRNA phenotypes in single or small 
numbers of cells. J. Cell Biochem. 39: 1-11.

Reed, K.C. and D.A. Mann. 1985. Rapid transfer of DNA from agarose gels to nylon membranes. Nucleic Acids Res. 13: 7207-7221.

Rickles, R.J., A.L. Darrow, and S. Strickland. 1988. Molecular cloning of complementary DNA to mouse tissue plasminogen activator mRNA and its expression during F9 teratocarcinoma cell differentiation. J. Biol. Chem. 263: 15631569.

Saiki, R.K, D.H. Gelfand, S. Stoffel, S.J. Scharf, R. Higuchi, G.T. Horn, K.B. Mullis, and H.A. Erlich. 1988. Primer-directed enzymatic amplification of DNA with a thermostable DNA polymerase. Science 239: 487-491.

Saksela, O., D. Moscatelli, and D.B. Rifkin. 1987. The opposing effects of basic fibroblast growth factor and transforming growth factor beta on the regulation of plasminogen activator activity in capillary endothelial cells. I. Cell Biol. 105: 957-963.

Schultz, G.A. 1986. Utilization of genetic information in the preimplantation mouse embryo. In Experimental approaches to mammalian embryonic development (ed. J. Rossant and R.A. Pedersen|, pp. 239-265. Cambridge University Press, Cambridge.

Schultz, R.M., G.E. Letourneau, and P.M. Wassarman. 1979a. Program of early development in the mammal: Changes in patterns and absolute rates of tubulin and total protein synthesis during oogenesis and early embryogenesis in the mouse. Dev. Biol. 68: 341-359.

. 1979b. Program of early development in the mammal: Changes in the patterns and absolute rates of tubulin and total protein synthesis during oocyte growth in the mouse. Dev. Biol. 73: 120-133.

Sellers, A., J.J. Reynolds, and M.C. Meikle. 1978. Neutral metallo-proteinases of rabbit bone. Biochem. J. 171: 493-496.

Sherman, M.I., R. Gay, S. Gay, and E.J. Miller. 1980. Association of collagen with preimplantation and peri-implantation mouse embryos. Dev. Biol. 74: 470-478.

Solter, D. and B.B. Knowles. 1975. Immunosurgery of mouse blastocyst. Proc. Natl. Acad. Sci. 72: 5099-5102.

Solter, D., L. Shevinsky, B.B. Knowles, and S. Strickland. 1979. The induction of antigenic changes in a teratocarcinoma stem cell line (F9) by retinoic acid. Dev. Biol. 70: 515-521.

Spindle, A. 1980. An improved culture medium for mouse blastocysts. In Vitro 16: 669-674.

Strickland, S. and V. Mahdavi. 1978. The induction of differentiation in terato-carcinoma stem cells by retinoic acid. Cell 15: 393-403.

Strickland, S., E. Reich, and M.I. Sherman. 1976. Plasminogen activator in early embryogenesis: Enzyme production by trophoblast and parietal endoderm. Cell 9: 231-240.

Strickland, S., K.K. Smith, and K.R. Marotti. 1980. Hormonal induction of differentiation in teratocarcinoma stem cells: Generation of parietal endoderm by retinoic acid and dibutyryl cAMP. Cell 21: 347-355.

Strickland, S., J. Huarte, D. Belin, A. Vassalli, R.J. Rickles, and J.-D. Vassalli. 1988. Antisense RNA directed against the 3' noncoding region prevents dormant mRNA activation in mouse oocytes. Science 241: 680-684.

Sutherland, A.E., P.G. Calarco, and C.H. Damsky. 1988. Expression and function of cell surface extracellular matrix receptors in mouse blastocyst attachment and outgrowth. $J$. Cell Biol. 106: 1331-1348.

Tabor, S. and C.C. Richardson. 1987. DNA sequence analysis with a modified bacteriophage T7 DNA polymerase. Proc. Natl. Acad. Sci. 84: 4767-4771.

Thomas, P.S. 1980. Hybridization of denatured RNA and small
DNA fragments transferred to nitrocellulose. Proc. Nat1. Acad. Sci. 77: 5201-5205.

Unemori, E.N. and Z. Werb. 1986. Reorganization of polymerized actin: A possible trigger for induction of procollagenase in fibroblasts cultured in and on collagen gels. J. Cell Biol. 103: $1021-1031$.

1988. Collagenase expression and endogenous activation in rabbit synovial fibroblasts stimulated by the calcium ionophore A23187. J. Biol. Chem. 263: 16252-16259.

Unemori, E.N., J.R. Chin, Z. Werb, and M. Bissell. 1987. Expression and vectorial secretion of extracellular matrix degrading enzymes by mammary epithelial cells. J. Cell Biol. 105: $217 \mathrm{a}$.

Valinsky, J.E. and N.M. Le Douarin. 1985. Production of plasminogen activator by migrating cephalic neural crest cells. $E M B O$ \%. 4: 1403-1406.

Wartiovaara, J., I. Leivo, and A. Vaheri. 1979. Expression of the cell surface-associated glycoprotein, fibronectin, in the early mouse embryo. Dev. Biol, 69: 247-257.

Werb, Z. 1989. Proteinases and matrix degradation. In Textbook of rheumatology (ed. W.N. Kelley, E.D. Harris, Jr., S. Ruddy, and C.B. Sledge), chap. 18. pp. 300-321. W.B. Saunders, Philadelphia.

Werb, Z., C.L. Mainardi, C.A. Vater, and E.D.Harris, Jr. 1977. Endogenous activation of latent collagenase by rheumatoid synovial cells. Evidence for a role of plasminogen activator. N. Engl. I. Med. 296: 1017-1023.

Werb, Z., R.M. Hembry, G. Murphy, and J. Aggeler. 1986. Commitment to expression of the metalloendopeptidases, collagenase and stromelysin: Relationship of inducing events to changes in cytoskeletal architecture. I. Cell Biol. 102: 697702.

Wessel, G.M. and D.R. McClay. 1987. Gastrulation in the sea urchin embryo requires the deposition of crosslinked collagen within the extracellular matrix. Dev. Biol. 121: 149165.

Whitham, S.E., G. Murphy, P. Angel, H.-J. Rahmsdorf, B.J Smith, A. Lyons, T.J.R. Harris, J.J. Reynolds, P. Herrlich, and A.J.P. Docherty. 1986. Comparison of human stromelysin and collagenase by cloning and sequence analysis. Biochem. J. 240: 913-916.

Wiley, L.M., A.I. Spindle, and R.A. Pedersen. 1978. Morphology of isolated mouse inner cell masses developing in vitro. Dev. Biol. 63: $1-10$.

Wilhelm, S.M., I.E. Collier, A. Kronberger, A.Z. Eisen, B.L. Marmer, G.A. Grant, E.A. Bauer, and G.I. Goldberg. 1987. Human skin fibroblast stromelysin: Structure, glycosylation, substrate specificity, and differential expression in normal and tumorigenic cells. Proc. Natl. Acad. Sci. 84: $6725-6729$. 


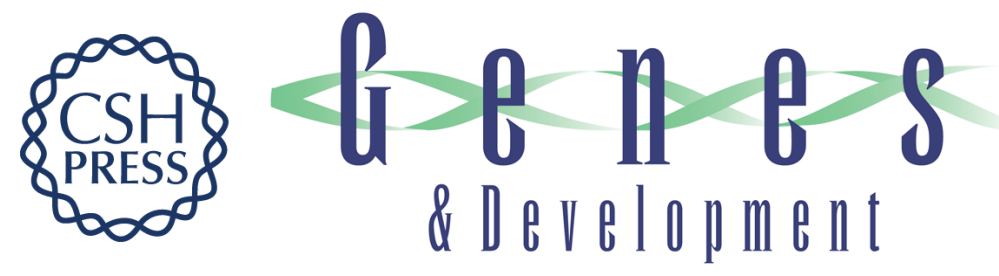

\section{Genes for extracellular-matrix-degrading metalloproteinases and their inhibitor, TIMP, are expressed during early mammalian development.}

C A Brenner, R R Adler, D A Rappolee, et al.

Genes Dev. 1989, 3:

Access the most recent version at doi:10.1101/gad.3.6.848

References This article cites 73 articles, 31 of which can be accessed free at: http://genesdev.cshlp.org/content/3/6/848.full.html\#ref-list-1

License

Email Alerting Service

Receive free email alerts when new articles cite this article - sign up in the box at the top right corner of the article or click here.

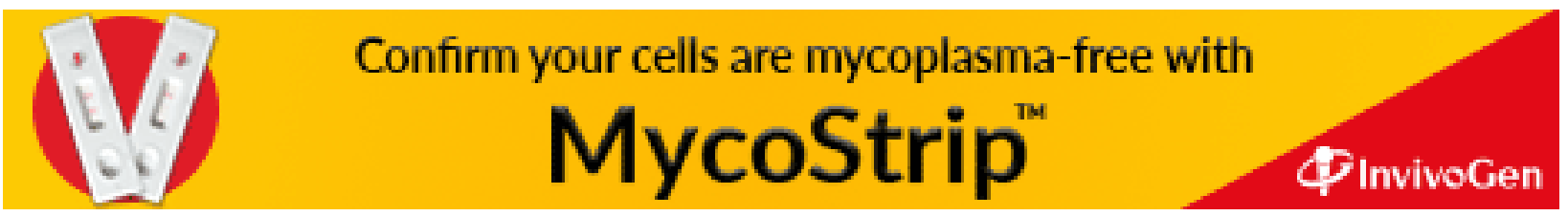

